\title{
Monitoring of effectiveness of bird flight diverters in preventing bird mortality from powerline collisions in Slovakia
}

\author{
Monitoring účinnosti odkloňovacích prvkov z pohl'adu prevencie úmrtnosti vtákov \\ v dôsledku nárazov do elektrických vedení na Slovensku
}

\author{
Marek GÁLIS \& Michal ŠEVČÍK
}

\begin{abstract}
Flight observations and carcass searches were carried out along distribution power lines in Slovakia. $77 \mathrm{~km}$ of $22 \mathrm{kV}$ and $110 \mathrm{kV}$ lines were marked on a total of 108 sections to evaluate the effectiveness of three types of bird flight diverters (FireFly Bird Diverter, RIBE Bird Flight Diverter and SWAN-FLIGHT Diverter) designed to increase power line visibility. Numbers of carcasses were compared before and after installation of the devices and reaction distances on marked power lines were surveyed. We observed a $93.5 \%$ reduction (93 vs. 6) in the number of fatalities under the marked power lines after line marking (06/2016-06/2019) compared to the period before installation (12/2014-02/2016). 2,296 flight reactions were observed and an estimated total of 41,885 individuals ( 57 bird species belonging to 13 orders) were recorded with their reactions to marked lines in the period 06/2016-06/2019. After installation of bird diverters, there was a low proportion of flight distance observations at the closest distance, i.e. up to $5 \mathrm{~m}$, indicating that birds reacted further away from marked lines. Although we lack flight observations for the period before the installation of diverters, the reactions of birds at greater distances and reduced number of bird victims under marked lines indicate that all tested diverters have a positive effect on reducing the number of avian collisions with power lines.
\end{abstract}

\begin{abstract}
Abstrakt: Monitoring reakcií vtákov a vyhl’adávanie uhynutých jedincov boli realizované pozdíž distribučných elektrických vedení na Slovensku. Na 108 označených úsekoch $22 \mathrm{kV}$ a $110 \mathrm{kV}$ vedení v dížke 77 km bola hodnotená efektivita troch typov odkloňovacích prvkov (FireFly Bird Diverter, RIBE Bird Flight Diverter a SWAN-FLIGHT Diverter), určených na zvýšenie viditel'nosti elektrických vedení. Porovnávali sme počet uhynutých jedincov pred a po inštalácií odkloňovacích prvkov a sledované boli reakcie a reakčné vzdialenosti na ošetrených vedeniach. Po inštalácií odkloňovacích prvkov (06/2016 - 09/2019) bolo v porovnaní s obdobím pred inštaláciou (12/2014 - 02/2016) zistené 93,5 \% zníženie (93 vs. 6) úmrtnosti jedincov. V období (06/2016 - 09/2019) sme na ošetrených vedeniach zaznamenali 2296 reakcií vtákov v počte približne 41885 reagujúcich jedincov (57 druhov patriacich do 13 radov). Po inštalácií odkloňovacích prvkov bola pozorovaná nižšia početnost' reakcií vo vzdialenosti do $5 \mathrm{~m}$, čo naznačuje, že jedince reagovali na ošetrené vedenia vo väčśích vzdialenostiach. Napriek tomu, že nebol realizovaný monitoring reakcií vtákov pred inštaláciou odkloňovacích prvkov, môžeme na základe zaznamenaných reakcií vo väčších vzdialenostiach od ošetrených vedení a zníženého počtu úhynov konštatovat', že všetky tri hodnotené typy odkloňovacích prvkov majú pozitívny efekt z hl'adiska redukcie početnosti nárazov do elektrických vedení.
\end{abstract}

Key words: avian collisions, FireFly Bird Diverter, RIBE Bird Flight Diverter, SWAN-FLIGHT Diverter, mitigation measures

\footnotetext{
Marek Gális, Raptor Protection of Slovakia, Trhová 54, 84101 Bratislava 42, Slovakia. E-mail: galis@dravce.sk.

Michal Ševčík, Department of Ecology and Environmental Sciences, Faculty of Natural Sciences, Constantine the Philosopher University in Nitra, Tr. A. Hlinku 1, 94974 Nitra, Slovakia.

Acknowledgments: The results were obtained and analyzed within the project LIFE13 NAT/SK/001272 Energy in the land power lines and conservation of priority bird species in Natura 2000 sites (www.lifeenergia.sk), supported by the European Commission under the LIFE programme and the Ministry of Environment of the Slovak Republic. We would like to thank to all field assistants for their participation in monitoring power lines and collecting data in very difficult weather conditions, namely: M. Boroš, J. Brndiar, P. Cibula, D. Csepányiová, V. Drahovský, E. Hapl, M. Jarošíková, L. Kňazovičová, P. Laboš, D. Lőbbová, L. Majdanová, P. Petluš, V. Petlušová, J. Ratičák, Z. Riflik, R. Slobodník, J. Šmídt, M. Szabo, M. Šara, A. Tulisová \& M. Zemko. We wish to thank anonymous reviewers and the executive editor for the valuable comments on the text.
} 
Gális M \& Ševčík M: Monitoring of effectiveness of bird flight diverters in preventing bird mortality

from powerline collisions in Slovakia

\section{Introduction}

Around the world, the availability of electricity has become an indicator of the standard of living. The transmission of electricity from power plants to users is mainly via overhead power lines. World-wide, this "wiring" of the landscape continues to increase and to advance even into the most remote parts of the inhabited continents. Most powerlines constructed so far pose fatal risks for a wide range of bird species and significantly affect the habitats of large birds in terms of their breeding, staging and wintering areas (Perrins \& Sears 1991, Savereno et al. 1996, Bevanger 1998, Janss \& Ferrer 2000, Coleman et al. 2001, Haas et al. 2005). Mortality from collisions with power lines and other electric utility structures has been documented for some 350 bird species (Manville 1999) with possible population level impacts (APLIC 1994, Janss \& Ferrer 2000, Bevanger \& Brøseth 2004, APLIC 2012, Loss et al. 2012, Rioux et al. 2013, Bernardino et al. 2018).

Collisions of birds with power lines are related to the main cause: the flying individual is unable to register such an obstacle ahead. Problems of collisions with power lines can be generally divided into three main categories based on factors of origin, including species-specific factors, site-specific factors and power line-specific factors (Bernardino et al. 2018). Frequently they can be observed especially in open areas where the power line crosses feeding, foraging and nesting habitats (APLIC 2012) used by birds, and can occur equally with transmission and distribution lines (Bevanger \& Brøseth 2004, Bahat 2008, Jenkins et al. 2010). Overhead lines are significant sources of avian collision mortality, particularly at dusk and dawn, and during the night when the lines are effectively invisible (APLIC 1994, Brown \& Drewien 1995, Janss \& Ferrer 2000). Some bird species which are active in the vicinity of power lines are more susceptible to collision risk than others. Morphology also plays a decisive role (Brown 1993, Bevanger 1998, Janss 2000, Crowder \& Rhodes 2002). Birds with low maneuverability, i.e. those with high wing loading and low aspect, such as bustards, pelicans, waterfowl, cranes, storks and grouse, are among the species most likely to collide with power lines (Bevanger 1998, Janss 2000, Shaw et al. 2010, Quinn et al. 2011, Barrientos et al. 2012). Species with narrow visual fields are also at high collision risk as they do not see the wires (Martin \& Shaw 2010, Martin 2011). Power line features can also influence the risk of bird collision based on different power line voltage (Shaw et al. 2018) and thus configuration, especially including the number of vertical levels (Drewitt \& Langston 2008, Jenkins et al. 2010), wire height (Haas et al. 2005, Murphy et al. 2009) and presence of shield wire (Murphy et al. 2009, APLIC 2012).

Many species in the highest survival risk categories are threatened, and reducing power line collision rates may therefore play an important role in their population persistence. The loss of a few or even one individual may impact a local population or the overall population's viability (Crowder 2000). Collisions with power lines are also a problem for power supply companies due to the possible power outages following collisions (collision-electrocution) and resulting financial losses (Haas et al. 2005, Bahat 2008).

Even if collisions themselves cannot be completely eliminated, they can still be reduced by means of proper mitigation measures. Line marking is one of the best solutions, based on making the wires more visible to birds in flight (Morkill \& Anderson 1991, Brown \& Drewien 1995, Frost 2008, Jenkins et al. 2010). This has become the preferred mitigation option worldwide. A wide range of potential line marking devices has evolved over the years, including avian balls, swinging plates, spiral vibration dampers, strips, ribbons, tapes, plates, flags and crossed bands (APLIC 2012). The effect of marking lines has varied widely across studies, primarily with habitat, bird species, season and type and configuration of power lines (Koops 1994, Bevanger \& Brøseth 2004, Wright et al. 2008, Mojica et al. 2009). Barrientos et al. (2011) reviewed 21 wire marking studies and similarly concluded that wire marking reduced bird mortality by $55-94 \%$. Understanding the nature of bird collisions is essential for minimizing them.

To date, fewer studies have attempted to reduce avian collisions with distribution power lines (Bevanger \& Brøseth 2004, Yee 2007, Barrientos et al. 2012), and more attention has been paid to transmission power lines (Savereno et al. 1996, Janns \& Ferrer 2000, De La Zerda \& Rosselli 2002, Bevanger \& Brøseth 2004, Frost 2008, Murphy et al. 2009, Sporer et al. 2013).

In this study a total of 77 kilometers of distribution power lines rated $22 \mathrm{kV}$ and $110 \mathrm{kV}$ in Slovakia were equipped with almost 8,000 devices representing three types of bird fight diverters: FireFly Bird Diverter, black and white RIBE Bird Flight Diverter and orange spiral SWAN-FLIGHT Diverter (SFD). The exact locations of spans suggested for installation of devices, were selected within the LIFE Energy project based on the results of special methodology evaluating electric power line risk levels from the viewpoint of bird deaths caused by 
collision with power lines and based on the technical possibilities (load capacity of phase conductors) of selected power lines. Placement of devices was selected to ensure that each device covered all types of habitats (same/different site specific conditions and bird species composition) present in the project area. The main aim was to study the effectiveness of the selected bird diverters by comparing the bird mortality before/after installation and by monitoring bird reactions and reaction distances to marked power lines. Preliminary results of our findings were published in studies by Gális et al. (2016, 2017, 2018a, 2018b) and Šmídt \& Gális (2018).

\section{Material and methods}

\section{$\mathrm{Stud} \mathrm{y}$ a r e a}

Monitoring the effectiveness of three types of bird diverters was carried out on 108 selected sections of power lines. The project area was located in the southern part of Slovakia (Fig. 1), in lowland agricultural landscapes. The selected surveyed area is of high avifaunal importance, including high bird populations and high percentages of migratory birds (Karaska et al. 2015). Agricultural fields and ponds also attract many bird species due to the presence especially of grain crops, oilseed rape and rodents. Many of the marked lines were very close to wetlands, marshes, rivers, lakes and ponds. The exact locations of all marked sections of $22 \mathrm{kV}$ and $110 \mathrm{kV}$ power lines can be found at page https://www.lifeenergia.sk/.
Selection of power lines suggested for installation of

bird flight diverters

In the period between 12/2014-02/2016 6,235 km of power lines were inspected twice during two periods (12/2014-3/2015 and 04/2015-02/2016) of field survey. In addition to this, intensive research was conducted during the second field survey at one-month intervals on power lines identified as the most dangerous for birds to collide with. The main focus of this survey was on collision, to recognize the range of the problem and its relevance for different bird species, habitats and power line configurations. Thirteen mitigation plans were designed for the project area with recommendations of particular measures for each Special Protection Area (SPA) and neighbouring area (Fig. 1), including the installation of bird flight diverters. $1,120 \mathrm{~km}$ of power lines were included in the group of hot spots $(17.9 \%$ of all inspected power lines) concerning the relative risk of collision evaluated. Out of this, $77 \mathrm{~km}$ were given the highest priority and were proposed for installation of three bird flight diverters. The exact method of selection of these highest priority sections is described in Šmídt et al. (2019).

Mortality surveys under marke d pow e r line s

Systematic carcass searches were conducted during 12/2014-02/2016 along $77 \mathrm{~km}$ of power lines before the

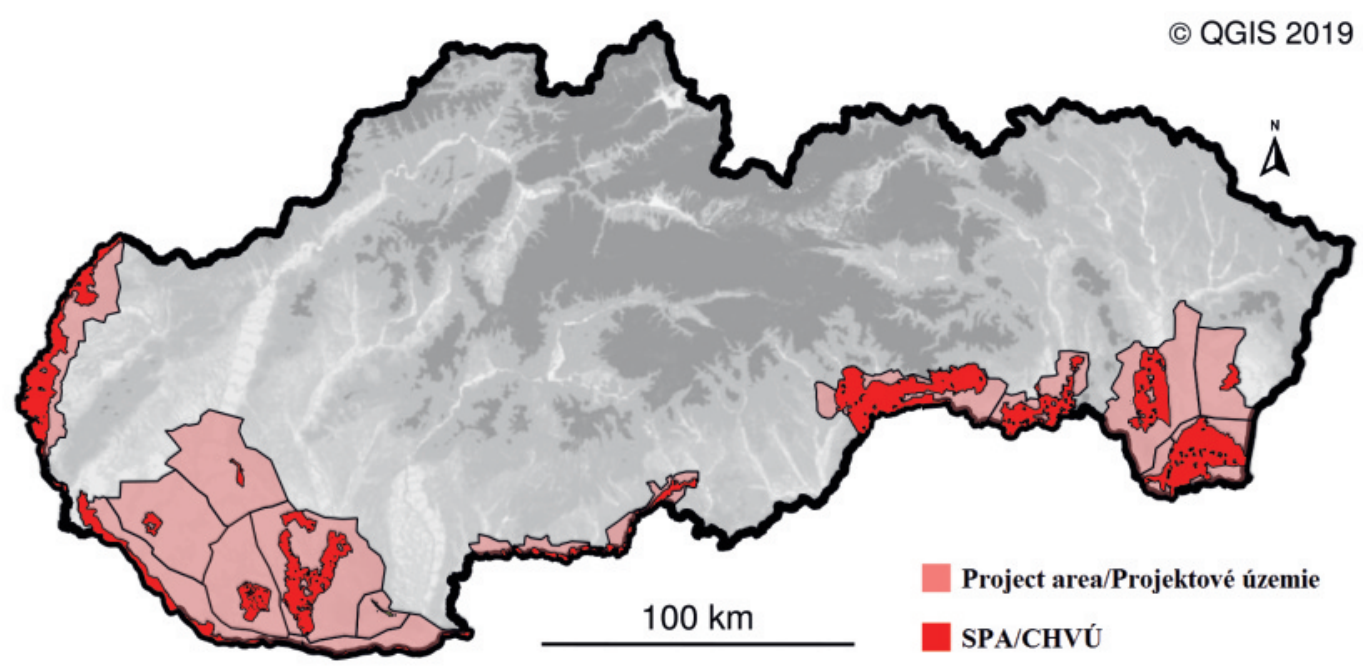

Fig. 1. All marked lines were situated within the project area covering 13 Special Protection Areas (SPA) and their adjacent areas. Obr. 1. Všetky ošetrené vedenia sa nachádzali $v$ rámci projektového územia pozostávajúceho z 13 Chránených vtáčích území (CHVÚ) a ich prilahlého okolia. 
Gális M \& Ševčík M: Monitoring of effectiveness of bird flight diverters in preventing bird mortality

from powerline collisions in Slovakia

installation of the first diverters, and then continued as carcass searches during 06/2016-06/2019 after diverters were put in place. Bird flight observations on marked lines also included carcass searches. Each marked line section was searched on foot before evening and after morning flight observation periods directly under the lines of $22 \mathrm{kV}$ and $110 \mathrm{kV}$ and two buffer zones $25 \mathrm{~m}$ from the center on either side of the line section (total $50 \mathrm{~m}$ buffer was checked). These line sections were monitored once per month. When a carcass or remains (e.g. feather scatter) were located, they were assigned an ID number, photographed, and identified to species whenever possible. GPS coordinates of each bird carcass or remains found were recorded, and carcass distance from the line estimated in meters. Cause of death was determined (if possible) in the field, and carcasses were collected out of the site, to prevent double counting during the next field survey.

The body condition of bird carcasses was also taken into account, to estimate the possible date of death. Altogether 21 field assistants were trained to ensure proper survey data collection. Moving in zig-zag pattern was performed only in high and dense vegetation. Nearby tree and shrub vegetation was inspected up to $100 \mathrm{~m}$, because injured birds often moved by themselves and hid because of bird fears, or were moved by a predator. All field assistants were trained by ornithologists and a GIS expert during two theoretical and two practical training sessions and several field meetings to ensure proper survey data collection for flight observations and also for mortality surveys. Theoretical training also consisted of analyses of video recordings of different types of reactions, to standardize the monitoring pattern between different assistants. The experts (in the position of supervisors) joined the field assistants during flight observations and field surveys to decrease searcher bias and ensure proper data collection and transcription. All marked line sections were divided among the field assistants, so the same assistant always searched and observed the same line.

All gathered data were verified and revised by experts in ornithology and recorded in an offline database. Monitoring was performed only in suitable weather and site conditions, to avoid unsuitable climatic factors (snowfall, rain) affecting bird activity. Results of carcass searches were not corrected for various bias factors including scavenger bias, crippling bias, habitat bias and searcher bias, analyzed in many studies (Bevanger 1999, Morrison 2002, Ponce et al. 2010, Jödicke et al. 2018).

\section{P o w e r line characteristics a n d b i d f i g h t d i v e r t e r s u s e d}

Two types of distribution power lines were selected for installation of bird diverters: a single/double circuit 22 $\mathrm{kV}$ line and double circuit $110 \mathrm{kV}$ line. The $110 \mathrm{kV}$ lines had one earth wire about the phase conductors as protection against lightning. The earth wire was located above the phase conductors as the highest part of the pylons. All vertical levels of phase conductors $(22 \mathrm{kV})$ and all levels of phase conductors + earth wire $(110 \mathrm{kV})$ were marked with bird flight diverters.

Three types of diverters commonly used for minimizing bird collisions worldwide were selected for testing their effectiveness: (A) FireFly Bird Diverter, a dynamic type of device produced by the Hammarprodukter company in Sweden. This is a high impact plastic plate with snapfast clamp that rotates in the wind at speeds $>8.04$ $\mathrm{km} / \mathrm{h}$. The FireFly utilizes reflective and UV absorption parts to prevent bird collisions during day and night. Only this device selected for our testing glowed for up to 10 to 12 hours after sunset. (B) SWAN-FLIGHT Di-
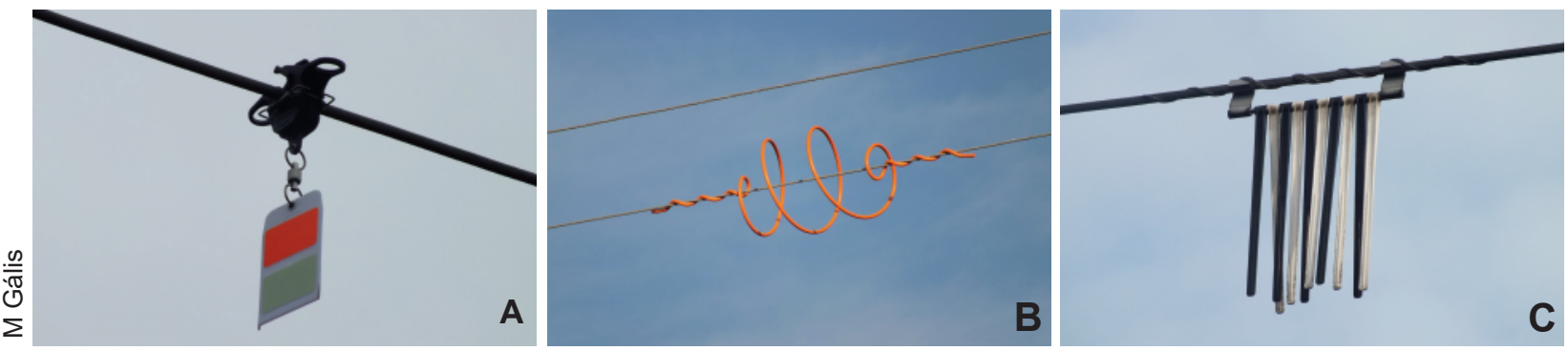

Fig. 2. FireFly Bird Diverter (A), SWAN-FLIGHT Diverter (B) and RIBE Bird Flight Diverter (C) selected for testing their effectiveness in preventing bird collisions.

Obr. 2. Odkloňovacie prvky FireFly Bird Diverter (A), SWAN-FLIGHT Diverter (B) a RIBE Bird Flight Diverter (C) vybrané pre testovanie ich efektivity $v$ prevencii pred nárazmi vtákov. 
verter, a double-ended spiral device from Spain. It is manufactured from high-impact PVC with UV protection and minimal wind resistance. Orange color was selected for our testing. (C) RIBE Bird Flight Diverter, with separate moving black and white strips sized $48 \times 30 \mathrm{~cm}$ with flashing effect contrasting with the surroundings (Fig. 2). All devices were attached at 10meter intervals. In the case of the RIBE Bird Flight Diverter, the selection of exact sections of power lines also depended on the age and thus the technical condition of the phase conductors, because of the product's weight. Only FireFly bird diverters were installed on $110 \mathrm{kV}$ lines (all levels of phase conductors + earth wire).

A total of 77 kilometers of distribution power lines rated $22 \mathrm{kV}(63 \mathrm{~km})$ and $110 \mathrm{kV}(14 \mathrm{~km})$ were marked with almost 8,000 diverter devices. The length of marked lines were: FireFly Bird Diverter $(30 \mathrm{~km}$ of 22 $\mathrm{kV})+(14 \mathrm{~km}$ of $110 \mathrm{kV})$, RIBE Bird Flight Diverter $(14 \mathrm{~km}$ of $22 \mathrm{kV})$ and SWAN-FLIGHT Diverter $(19 \mathrm{~km}$ of $22 \mathrm{kV}$ ). Installation was carried out from the ground, using a bucket truck and boat. Two types of special devices were used for installation of FireFly Bird Diverters on $110 \mathrm{kV}$ lines and on $22 \mathrm{kV}$ lines above rivers or in difficult terrain (Fig. 3).

\section{F l i g h t o b s e r vations}

Monitoring took place along $22 \mathrm{kV}$ and $110 \mathrm{kV}$ distribution power line sections with total length $77 \mathrm{~km}$, rated as having the most risk potential for possible bird collisions, immediately after diverters were installed in the period 06/2016-06/2019. It was done twice for each monitored day. (A) Morning, starting 0.5 hour before dawn, and continuing for another 1.5 hours after sunrise. (B) Evening, starting 1.5 hours before dusk and continuing for 0.5 hour after sunset. In these time periods the light conditions are insufficient and birds are most active at the same time, hence there is a high risk of possible collision. Total monitoring time was 4 hours/ day. Marked power lines were monitored once per month, but if the power line exhibited many repeated bird overflights, the frequency of bird flight observations increased. The goal was to capture as many birds' reactions as possible to confirm/refute the diverter effectiveness. We applied this approach to all marked lines. Moreover the presence of bird species in proximity to the marked power lines was monitored by experts in ornithology, and the intensity of flight observations were set based on the presence/absence of bird species.

One person monitored power lines in a 500-meter range of marked spans. Two persons carried out monitoring of sections longer than 500 meters, or if the power line changed direction significantly or it was divided by a barrier (e.g. horizon, vegetation).

For each monitored power line the following data were assessed: (1) location (ID), (2) date and time of monitoring, (3) observed time of sunrise and sunset, (4) biotope, vegetation close to $(<300 \mathrm{~m})$ the monitored section, (5) weather, wind direction and intensity converted to the Beaufort wind scale.

During the observation period, the occurrence of individuals and flocks was recorded. Flocks were considered to be two or more individual birds of the same species. The responses protocol consisted of 9 types for various reactions of an individual bird to the power line: (0) no reaction, (1) bird flew through the line with no reaction, (2) bird changed the primary course and flew through the line, (3) bird flew up and over line (4) bird flew down and under line, (5) bird turned the primary course and flew away from or along the line, (6) bird collided but continued in flight, (7) bird collided and fell dead or injured, (8) bird landed on line.

For reaction types 2, 3, 4 and 5 a reaction distance relative to the line was recorded according to three categories: (1) 0 $5 \mathrm{~m}$ from the line, (2) 6-25 m, and (3) $<25 \mathrm{~m}$ away. Distance did not apply for reaction types $0,1,6,7$ and 8 .

\section{Statistic a 1 a $n$ a 1 y s e s}

In all analyses only selected bird species were used (medium and large-sized birds with a higher susceptibility to collision) selected based on Bevanger (1998) categor-
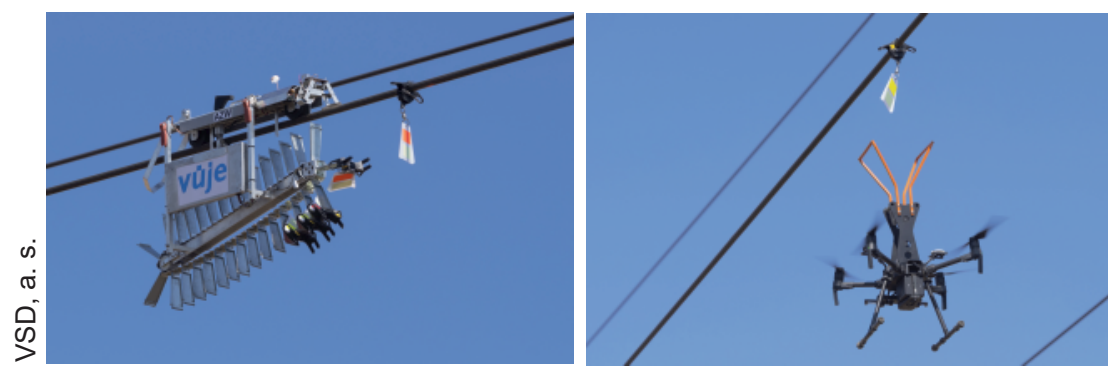

Fig. 3. Special devices constructed and used for installation of FireFlyBird Diverter in Slovakia (CVSD, s. s.

Obr. 3. Špeciálne zariadenia skonštruované a využité pri inštalácií prvku FireFly Bird Diverter na Slovenku CVSD, a. s. 
Gális M \& Ševčík M: Monitoring of effectiveness of bird flight diverters in preventing bird mortality

from powerline collisions in Slovakia

ization. They are frequently reported as collision victims (Janss 2000, Crowder \& Rhodes 2002, Rubolini et al. 2005). There were two types of bird responses to different diverters: reaction type and reaction distance. Because observing actual collisions is rare, statistical analyses were reserved for reaction types 2, 3 and 4, which represent positive reactions. Similarly as in the study by the Ventana Wildlife Society (2009), our variable reaction types represented counts of positive reactions (types: 2, 3 and 4) observed during each occasion (2-hour observing period). Differences in counts of positive reaction types between diverters were analyzed using the generalized linear mixed model (GLMM) with negative binomial error distribution and logarithmic link function (negative binomial distribution was used to account for overdispersion in the data). Because of the diversity of sampling over time and space, attributes of month and locality were used and tested as random factors. Although the amount of variability explained with months was negligible, the contribution of locality was considerable, so locality was used as the only random variable with varying intercept. The same type of model (GLMM with negative binomial error distribution) was used to compare positive reaction types between different power lines $(22 \mathrm{kV}$ vs. $110 \mathrm{kV})$ marked with FireFly Bird Diverter. Differences between reaction distances were analyzed using ordinal logistic regression with multilevel structure using the cumulative distribution function with the logit link function. As with reaction type analyses, localities helped explain a considerable amount of variability and were used as a random variable with varying intercept. The same type of model was also used to compare reaction distances between different power lines $(22 \mathrm{kV}$ vs $110 \mathrm{kV})$ marked with FireFly Bird Diverter. All analyses were created in the Bayesian framework using Stan language (http://mcstan.org/) accessed with the brms package (Bürkner 2017) in $\mathrm{R}$ ( $\mathrm{R}$ Core Team 2019). To improve convergence and guard against overfitting, we specified mildly informative conservative priors (population-level effects $=$ normal $(0,10)$; intercept and $\mathrm{sd}=$ student $\mathrm{t}(3,0,10)$; shape $=$ gamma $(0.01,0.01)$ To compare different models we used leave-one-out cross-validation (LOOCV) using Pareto smoothed importance sampling (PSIS) in the loo package (Vehtari et al. 2019). This framework provides more precise and informative intervals of estimated parameters (compared to the most frequently used penalized quasi-likelihood approximation) and automatically penalize more complex models, providing a way to select the best model. For further information see Bolker et al. (2009) and Gelman et al. (2013). The number of collisions was estimated based on carcass search results from the period before (12/2014-02/2016) and after (06/2016-06/2019) the diverters installation. Numbers of carcasses found were not corrected to account for carcass losses due to removal by scavengers or inadvertence in carcass detection by field assistants. Only raw numbers of dead birds found were used for calculation of mortality before/after diverters installation.

\section{Results}

M o r t a lity s u r v e y

A total of 93 bird carcasses belonging to 8 bird species were identified under the selected power lines $(77 \mathrm{~km})$, checked before installation of diverters, in the period from 12/2014 to 02/2016. Mute swans (Cygnus olor) were the most commonly encountered bird carcasses, accounting for 55 individuals $(59.2 \%)$ of the total, and 19 mallards (Anas platyrhynchos - 20.4\%), 6 great egrets (Ardea alba - 6.5\%), 4 passerines (4.4\%), 4 white storks (Ciconia ciconia - 4.3\%), 2 common pheasant (Phasianus colchicus - 2.1\%), 2 northern lapwings (Vanellus vanellus - 2.1\%) and 1 common pochard (Aythya ferina - 1\%) were also recorded. All identified bird carcasses were removed from the area to prevent double counts. Only 6 bird carcasses $(93.5 \%$ reduction in observed casualties) belonging to 2 bird species were

Tab. 1. Percentages of type of reaction (2, 3, 4 and 5) on marked power lines.

Tab. 1. Percentuálny podiel reakčného typu (2, 3, 4 a 5) na ošetrenom elektrickom vedení.

\begin{tabular}{|c|c|c|c|c|c|}
\hline $\begin{array}{l}\text { observed reaction type / number of records / } \\
\text { zaznamenaný typ reakcie / počet záznamov / }\end{array}$ & $\begin{array}{l}\text { all bird species I } \\
\text { všetky druhy vtákov } \\
n=2,296\end{array}$ & $\begin{array}{l}\text { swans / } \\
\text { labute } \\
\mathrm{n}=308\end{array}$ & $\begin{array}{l}\text { ducks } / \\
\text { kačice } \\
n=412\end{array}$ & $\begin{array}{l}\text { herons / } \\
\text { volavky } \\
n=303\end{array}$ & $\begin{array}{l}\text { geese / } \\
\text { husi } \\
n=153\end{array}$ \\
\hline $\begin{array}{l}\text { - through wires + maneuvering / } \\
\text { pomedzi vodiče + manévrovanie (\%) }\end{array}$ & 3.6 & 4.10 & 1.90 & 1.3 & - \\
\hline 3 - flew over / prelet ponad (\%) & 78.0 & 73.3 & 80.0 & 80.8 & 88.2 \\
\hline 4 - flew under / prelet popod (\%) & 10.6 & 7.7 & 9.3 & 8.3 & 3.2 \\
\hline $\begin{array}{l}5 \text { - changed previous direction / } \\
\text { zmena pôvodného smeru (\%) }\end{array}$ & 7.8 & 14.9 & 8.8 & 9.6 & 8.6 \\
\hline
\end{tabular}




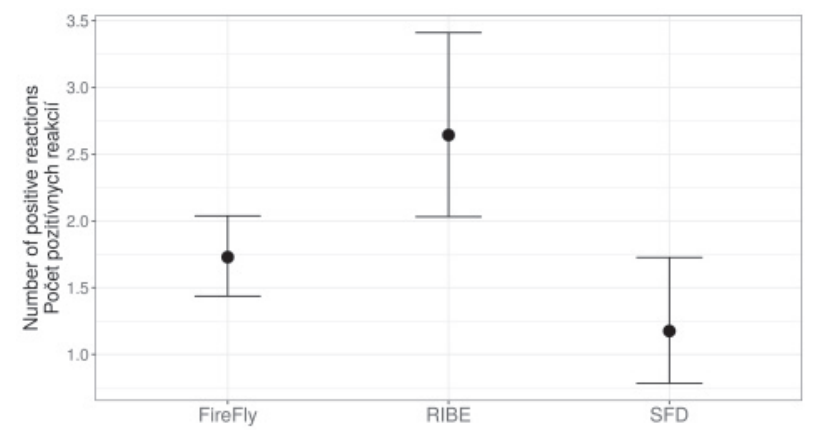

Fig. 4. Differences between diverters in terms of an estimated number of positive reactions represented with posterior means (solid points) and theirs 95\% credible intervals $(n=560)$. The number of positive reactions is highest for RIBE $(2.64[95 \% \mathrm{Cl}$ : $2.03,3.41])$ then FireFly $(1.73$ [95\% Cl: 1.44, 2.04]) and SWANFLIGHT Diverter (1.18 [95\% Cl: 0.78, 1.73]).

Obr. 4. Rozdiely $v$ odhadovaných počtoch pozitívnych reakcií pre každý odkloňovací prvok, vyjadrené priemermi pre jednotlivé odkloňovače (plné body) s ich $95 \%$ intervalmi dôveryhodnosti $(n=560)$. Počet pozitívnych reakcií bol najvyšší pre prvok RIBE $(2,64,95 \% \mathrm{Cl}[2,03,3,41])$, potom pre prvok FireFly $(1,73$ [95 \% Cl: $1,44,2,04])$ a prvok SWAN-FLIGHT $(1,18[95 \% \mathrm{Cl}$ : $0,78,1,73])$.

found only under marked $22 \mathrm{kV}$ power lines, checked immediately after installation, in the period from $06 / 2016$ to $06 / 2019$. After installation of diverters in 2016 and 2017, no collision victims were recorded. Two mute swans (both under the same line marked with FireFly Bird Diverter) and three great egrets (one under a line marked with FireFly and two with SWANFLIGHT Diverter) were killed in March 2018. One mute swan died after collision and consequent electrocution (line marked with RIBE Bird Flight Diverter) in January 2019.

F 1 i g h t o b s e r v a t i o n s

A total of 6,151 records and an estimated total of 75,175 individuals (95 bird species) were recorded during the flight observations in seasons from $06 / 2016$ to $06 / 2019$. Only in 2,296 flight observations, reaction type (2, 3, 4 and 5) was observed and an estimated total of 41,885 birds (57 bird species belonging to 13 orders) were recorded along the total length of $77 \mathrm{~km}$ of marked power lines $(63 \mathrm{~km}$ of $22 \mathrm{kV}$ and $14 \mathrm{~km}$ of $110 \mathrm{kV})$. Similar observations were made during the morning $(1,183)$ and during the evening period $(1,113)$. Of the 2,296 observations, birds crossed power lines during the study as follows: 1,791 times (78\%) they changed the altitude and flew above as they approached the line; 244 times

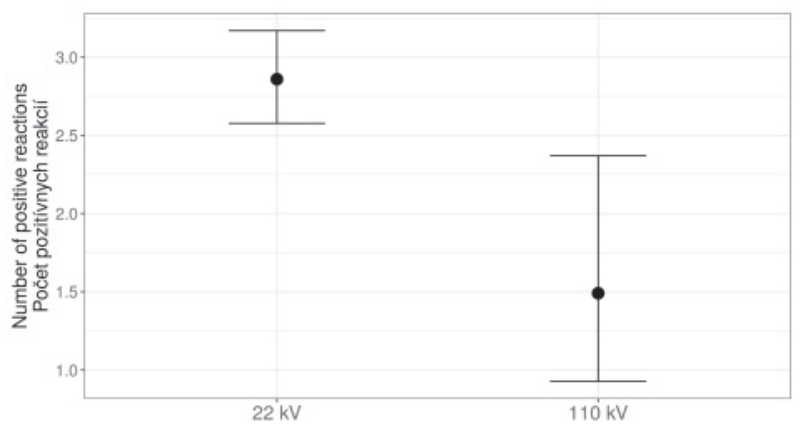

Fig. 5. Differences between different voltages of power lines (for FireFly Bird Diverter), in terms of an estimated number of positive reactions, represented with posterior means (solid points) and theirs $95 \%$ credible intervals $(n=250)$. The number of positive reactions is highest on $22 \mathrm{kV}$ lines $(22 \mathrm{kV}=2.86$ [95\% Cl: 2.58, 3.17]; 110 kV = 1.49 [95\% Cl: 0.93, 2.37]).

Obr. 5. Rozdiely v odhadovaných počtoch pozitívnych reakcií medzi linkami vysokého napätia (pre prvok FireFly), vyjadrené odhadmi priemerov (plné body) s ich $95 \%$ intervalmi dôveryhodnosti $(n=250)$. Počet pozitívnych reakcií je najvyšší na 22 kV linkách $(22$ kV = 2,86 [95\% Cl: 2,58, 3,17]; 110 kV = 1,49 [95 \% Cl: 0,93, 2,37]).

(10.6\%) they flew below and 179 times $(7.8 \%)$ they changed their primary direction or 82 times $(3.6 \%)$ they flew between the wires in double-circuit configuration of $22 \mathrm{kV}$ and $110 \mathrm{k} \mathrm{V}$ power lines (Tab. 1). The remaining percentage consisted of observations with no reactions, because the birds flew over at higher levels than the power lines.

There were considerable differences between the diverters in terms of positive reaction type (Fig. 4). In addition to the differences between the diverting devices themselves, the effects of several independent variables were also tested (monitoring time $=$ morning/evening; low visibility conditions $=$ rain, fog, snow, categorized as good/bad conditions; country part = west/ east; quantity $=$ individual/flock). Before considering the locality as a random factor, most of these independent variables had a significant effect, but with this random factor included, none of the two-way or three-way interactions between diverting and independent variables was credible (elpd diff (difference in expected log predictive density) $\leq$ standard error). This suggests that the specific characteristic of each locality has considerable influence on the effectiveness of different diverters.

After filtering only FireFly Bird Diverters, there were considerable differences between the types $(22 \mathrm{kV}$ and $110 \mathrm{kV}$ ) of power lines (Fig. 5). Similarly as in the 

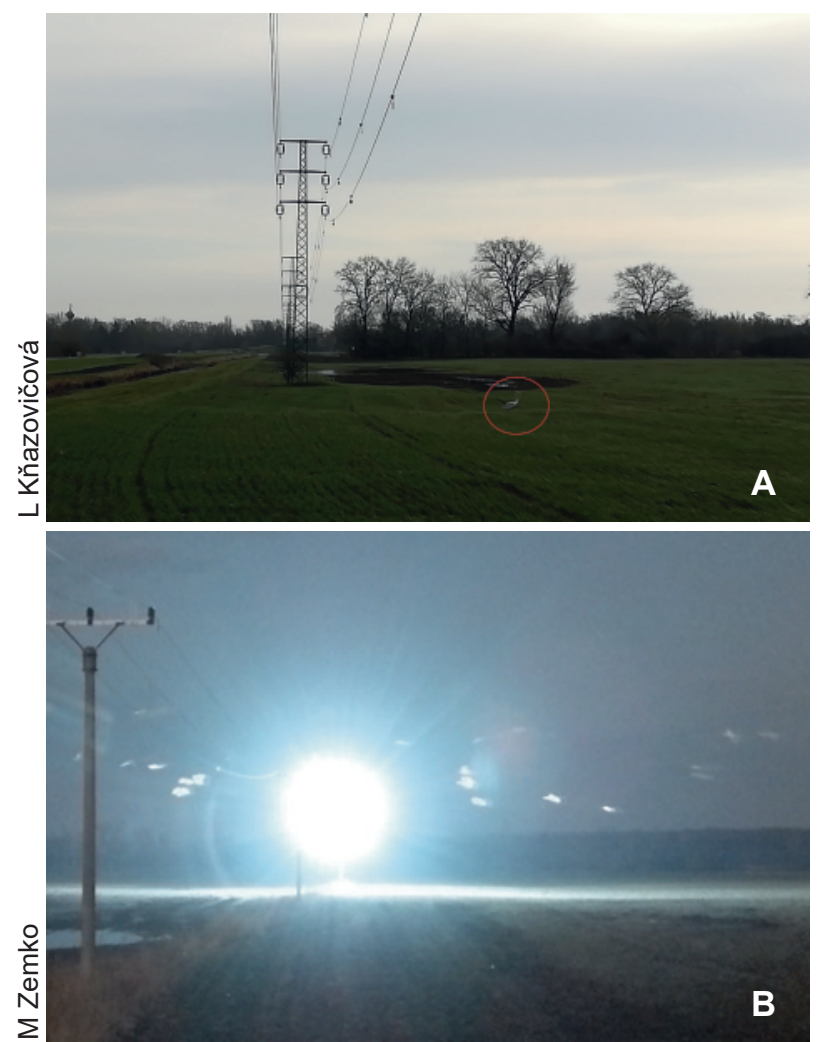

Fig. 6. Young mute swan after collision with double circuit $22 \mathrm{kV}$ line marked with FireFly continued to fly (A) and power outage (B) recorded on $22 \mathrm{kV}$ line marked with RIBE diverters after collision of mute swan as the bird crossed as a member of a big flock.

Obr. 6. Mladá labut' po náraze do dvojitého vedenie $22 \mathrm{kV}$ ošetreného prvkom FireFly pokračovala v lete $(A)$ a záblesk (B) zaznamenaný na vedení $22 \mathrm{kV}$ ošetrenom prvkom RIBE, po náraze jednej z labutí počas preletu početného kŕdla.

differences between the diverters in terms of positive reaction type, after accounting for the locality factor, none of the interactions with independent variables (monitoring time, visibility conditions, country part, quantity) was credible.

Observations of collisions were rare during our study (Fig. 6). Only two collisions were observed during a survey of marked lines. A young mute swan hit a $22 \mathrm{kV}$ line marked with FireFly Bird Diverters on 29 March 2018 at 8:20 a.m. The observer stated that it was a collision based on the sound and movement of the lowest phase conductor as the bird crossed the line. The mute swan hit the ground after the collision, but after less than two minutes it continued to fly again and did not appear injured. A second collision of a mute swan

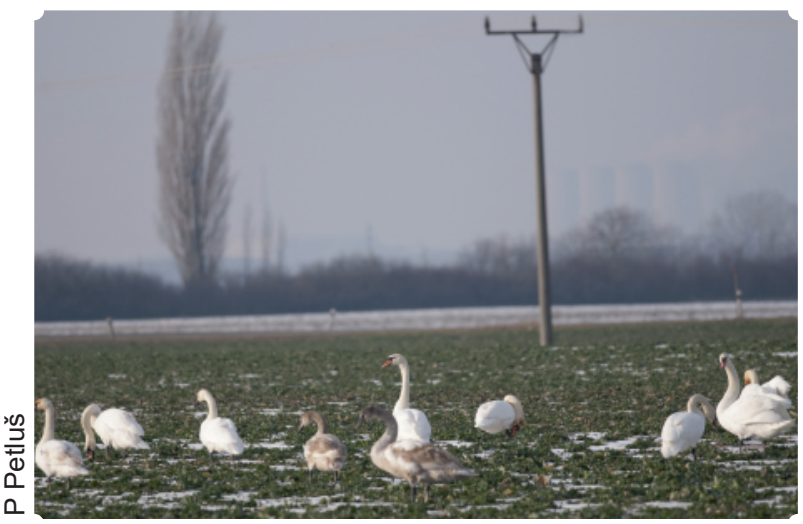

Fig. 7. Mute swans feeding in oilseed rape fields with power lines in close proximity.

Obr. 7. Labute vel'ké kŕmiace sa na repkovom poli $v$ tesnej blízkosti elektrického vedenia.

was recorded on digital camera on a $22 \mathrm{kV}$ power line marked with RIBE Bird Flight Diverter on 17 January 2019 at 16:59 p.m. One mute swan hit the wires as the bird crossed (in $78^{\text {th }}$ position) as a member of a big flock of 150-170 swans and caused an outage, confirmed by the distribution network operator.

Spring growth of winter wheat and oilseed crops on surrounding arable land provides a timely alternative food supply for the swans and geese, resulting in large numbers flying out of the wetlands to feed in these fields, returning to the wetlands for safe refuge when they cease feeding (Fig. 7). From the middle of April onwards grazing of the winter wheat and oilseed decreases as the crop becomes too tall and the swans disperse to their breeding or moulting grounds.

For altitude change and flutter/flare reaction types, the recorded distances of the reactions from the marked power lines were evaluated for all bird species. Swans, ducks, herons and geese were separated from other bird species, as they are among the species most likely to collide with power lines (Bevanger 1998).

After treatment there was a lower proportion of distance observations in the closest distance category (i.e. distance category 1, 0-5 m away from the line) (Tab. 2). Conversely, proportions in the more distant categories $2(6-25 \mathrm{~m})$ and 3 $(>25 \mathrm{~m})$ were more than half, indicating that birds reacted further from lines after diverters were installed.

In the case of reaction distances on marked lines, there was no credible difference between diverters (all diverters had similar effect), but there was considerable difference between closer and farther reaction distances (Fig. 8). 
Tab. 2. Percentage of reaction records in each distance category on marked power lines.

Tab. 2. Percentuálny podiel záznamenaných reakcií v jednotlivých reakčných zónach na ošetrených vedeniach.

\begin{tabular}{|c|c|c|c|c|c|}
\hline $\begin{array}{l}\text { reaction distance / number of records / } \\
\text { reakčná vzdialenost' / počet záznamov }\end{array}$ & $\begin{array}{c}\text { all bird species / } \\
\text { všetky druhy vtákov } \\
n=2296\end{array}$ & $\begin{array}{l}\text { swans I } \\
\text { labute } \\
\mathrm{n}=308\end{array}$ & $\begin{array}{l}\text { ducks / } \\
\text { kačice } \\
n=412\end{array}$ & $\begin{array}{l}\text { herons I } \\
\text { volavky } \\
n=303\end{array}$ & $\begin{array}{c}\text { geese / } \\
\text { husi } \\
\mathbf{n}=153\end{array}$ \\
\hline $1(0-5 \mathrm{~m})(\%)$ & 19.0 & 13.7 & 13.3 & 11.8 & 14.4 \\
\hline $2(6-25 \mathrm{~m})(\%)$ & 43.4 & 50.90 & 43.2 & 42.9 & 35.2 \\
\hline $3(>25 \mathrm{~m})(\%)$ & 37.6 & 35.40 & 43.5 & 45.3 & 50.4 \\
\hline
\end{tabular}

Similarly as in the reaction type models, after accounting for locality as a random factor, none of the independent variable interactions had credible effect except quantity (individual/flock), which had a slightly positive impact on the predictive accuracy of the model (elpd diff $=-8.5 ; \mathrm{SE}=4.8$ ) (Fig. 9).

In terms of power lines, we can see similar behavior with $22 \mathrm{kV}$ and $110 \mathrm{kV}$ lines (Fig. 10).

\section{Discussion}

As mentioned in many expert studies, the presence of bird flight diverters is associated with a decrease in collision mortality (Morkill \& Anderson 1991, Brown \& Drewien 1995, Frost 2008, Jenkins et al. 2010, Sporer et al. 2013). Placement of various designs of diverter devices on wires has been shown to effectively reduce bird collisions in a range between 55 to $94 \%$ (Barrientos et al. 2011). Evaluating the efficacy of diverters relies heavily on comparing the number of dead birds found under marked and non-marked power lines. We compared the carcass mortality along distribution power lines before and after installation of three types of bird flight diverters. There was a considerable reduction in bird collision rates in response to the fitting of diverters, namely by $93.5 \%(06 / 2016-06 / 2019)$ comparing the years before (12/2014-02/2016) - 93 vs. 6 bird carcasses. All carcasses were found within $25 \mathrm{~m}$ of the power lines, indicating that the designated search area $(50 \mathrm{~m})$ provided sufficient opportunity to find carcasses of birds having collided with monitored $22 \mathrm{kV}$ and 110 $\mathrm{kV}$ distribution power lines. The occurrence of fewer collision victims under marked lines provides some evidence that all selected types of flight diverters are effective and have positive impact on reducing avian collisions.

The presence of identified bird carcasses (93 vs. 6) may not reflect reliably the results of bird mortality surveys carried out under power lines before and after diverter installation. Although we tried to minimize the sampling biases, it is possible to expect that the final mortality may be higher due to such biases.
Especially for bird collisions, crippling loss bias could also increase the real mortality associated with power lines, as after colliding with the power line an injured bird may move on and out of the search area. This sort of case was recorded in our observations, as one mute swan hit the ground after collision with a marked line, but after less than two minutes continued to fly again and did not appear injured (but could have died later as a result of internal injuries). Many birds injured after collisions could move far enough away from the power line before dying, and thus they are not found during carcass searches, even if the designated search area is sufficient. The study by Bevanger (1999) cites

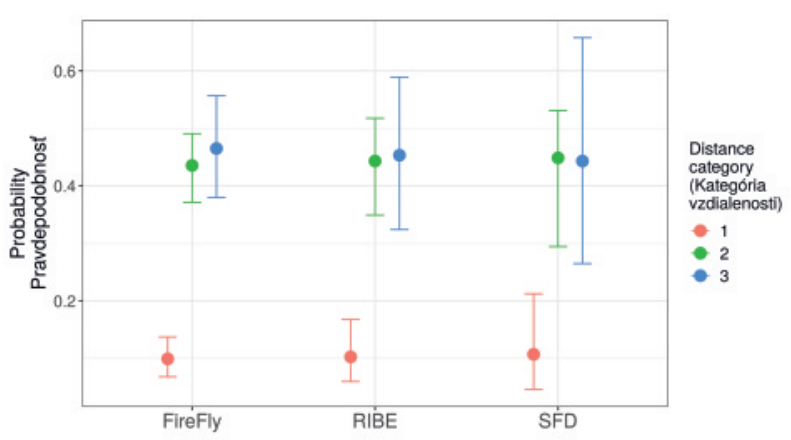

Fig. 8. Probability of individual reaction distances (category 1-3) for each type of bird diverter. Solid points show the mean of fitted posterior distribution and theirs $95 \%$ credible intervals $(\mathrm{n}=$ 1251). While marginal the most credible difference between first and second reaction distances for all diverters was 33.2\% [95\% $\mathrm{Cl}: 29.0,37.4]$, between first and third it was $35.1 \%[95 \% \mathrm{Cl}$ : $22.6,46.8]$ and between third and second it was $1.5 \%[95 \% \mathrm{Cl}$ : $-11.5,16.7]$, what suggests a higher likelihood of early bird response to marked power lines.

Obr. 8. Pravdepodobnost' jednotlivých reakčných vzdialeností (kategórie 1 - 3) pre každý odkloňovací prvok. Pevné body znázorňujú odhadnuté priemery s ich $95 \%$ intervalmi dôveryhodnosti ( $n=1251)$. Zatial' čo celkový rozdiel (cez všetky prvky), medzi prvou a druhu vzdialenostnou kategóriou bol 33,2 \% [95\% Cl: 29,0, 37,4], bol medzi prvou a tret'ou 35,1\% [95\% Cl: $22,6,46,8]$ a medzi tret'ou a druhou $1,5 \%[95 \% \mathrm{Cl}:-11,5,16,7]$, čo značí vyššiu pravdepodobnost' skoršej reakcie vtákov na ošetrené elektrické vedenie. 
Gális M \& Ševčík M: Monitoring of effectiveness of bird flight diverters in preventing bird mortality

from powerline collisions in Slovakia

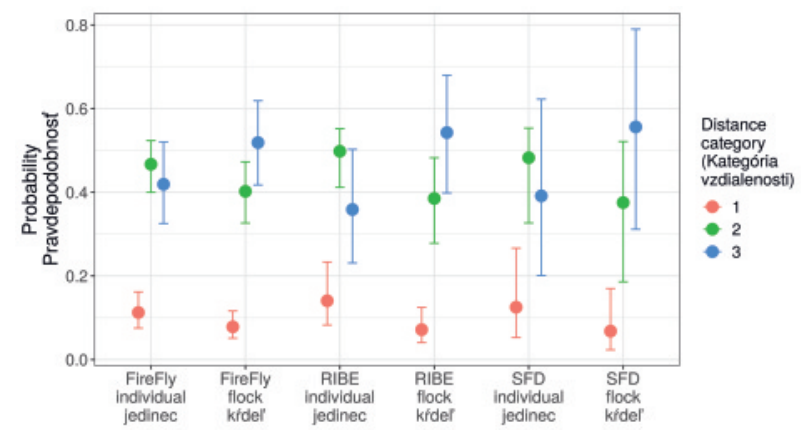

Fig. 9. Probability of birds reaction distances (category 1-3) for each type of bird diverter based on their quantity (individual or flock). Solid points show fitted values: the mean of posterior distribution and theirs $95 \%$ credible intervals $(n=1251)$. While marginal the most credible difference between individuals and flocks in first reaction distance cross all diverters was $5.5 \%$ [95\% Cl: $2.1,9.6]$, and $8.9 \%$ [95\% Cl: $3.7,15.3]$ at the second reaction distance and $14.5 \%[95 \% \mathrm{Cl}:-0.23,-6.3]$ at the third reaction distance, what suggests, that flocks have a higher likelihood of early response to power lines.

Obr. 9. Pravdepodobnost' jednotlivých reakčných vzdialeností (kategórie 1 - 3) pre každý odkloňovací prvok na základe početnosti (jedinec, alebo kŕdel'). Pevné body znázorňujú odhadnuté priemery s ich $95 \%$ intervalmi dôveryhodnosti $(\mathrm{n}=$ 1251). Celkový rozdiel (cez všetky odkloňovače), medzi jedincami a kŕdl'ami pre prvú vzdialenostnú kategóriu je 5,5\% [95\% $\mathrm{Cl}: 2,1,9,6], 8,9 \%$ [95\% Cl: 3,7, 15,3], druhú 8,9 \% [95\% Cl: $3,7,15,3]$ a tretiu $14,5 \%[95 \% \mathrm{Cl}:-0,23,-6,3]$, čo značí, že kŕdle majú vyššiu pravdepodobnost' skoršej reakcie na elektrické vedenie, ako jednotlivec.

several studies which found $22 \%$ (Hiltunen 1953) to 50\% (Renssen et al. 1975) and even 74\% (Beaulaurier 1981) of possible crippling loss bias. Crippling loss bias estimates are extremely difficult to obtain, and they are the least likely to be calculated (APLIC 2012).

The same observers were used throughout the mortality surveys to minimize observer bias, which may in some cases reach the level of only $45 \%$ of small bird species being found in dense vegetation (Homan et al. 2001). Searcher efficiency is highly variable, with several studies reporting relatively low rates (i.e. $35 \%-$ $50 \%$ ) and others reporting relatively high rates (i.e. $75 \%-$ $85 \%$ ) of recovery (Morrison 2002). Efficiency is mainly influenced by the height and type of vegetation present and the bird species composition in the surveyed area. Moreover carcass removal by scavengers often biases the mortality surveys (Ponce et al. 2010), with very high initial removal rates among smaller carcasses, most of which disappear within the first few days (Prosser et al. 2008).

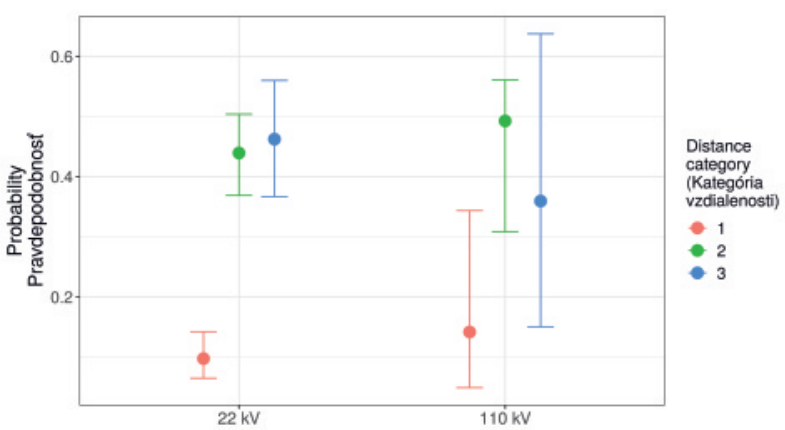

Fig. 10. Probability of bird reaction distances (category 1-3) (for FireFly Bird Diverter) in terms of different voltages lines. Solid points show fitted values: the mean of posterior distribution and $95 \%$ credible intervals $(n=787)$. In both types was estimated higher likelihood of early bird response to power lines. Increased uncertainty with $110 \mathrm{kV}$ was caused by the small number of observations.

Obr. 10. Pravdepodobnost' jednotlivých reakčných vzdialeností (kategórie 1 - 3) (pre FireFly odkloňovač) pri rôznych typoch elektrického vedenia. Pevné body znázorňujú odhadnuté priemery s ich $95 \%$ intervalmi dôveryhodnosti $(n=787$ ). Pri oboch typoch je vyššia pravdepodobnost' skoršej reakcie vtákov na elektrické vedenie. Zvýšená neistota pri 110 kV vedení je spôsobená nižším počtom pozorovaní.

It should be made clear that even if some bird flight diverters (FireFly Bird Diverter and RIBE Bird Flight Diverter) were found to be better, the percentage of positive reaction type for the "worst" diverter (SWANFLIGHT Diverter) was $91 \%$, and the differences between all diverters were only in the remaining few percent, hence the efficiency of all diverters was at a high level. Statistical analyses were reserved only for reaction types 2, 3 and 4, which represent positive reactions, and thus good diverter performance. Evaluating diverter effectiveness based on reaction type 5 (bird turned off the primary course and flew away from or along the line) was debatable. In our pattern for flight observations, it was thought that birds exhibiting this type of reaction in the closest distance category $(<5 \mathrm{~m})$ might have had difficulty seeing the marked line, and were therefore not selected for further statistical analyses as positive reaction. This type of reaction to marked lines could indicate lower diverter effectiveness. On the other hand, the presence of diverters and abrupt changes in primary flight course at the last moment could also indicate that diverters increased the line visibility for birds which would otherwise have collided with a non-marked wire.

The effectiveness of our devices was higher in comparison with spiral PVC vibration dampers (61\%) and 
fiberglass plates (63\%, Brown \& Drewien 1995), aviation balls (54\%, Moorkill \& Anderson 1991 and 53\%, Savereno et al. 1996) and SFD with $73 \%$ reduction (Crowder 2000). Using FireFly Bird Diverters, 60\% reduction in avian collisions was observed in sandhill crane collisions with $12 \mathrm{kV}$ distribution lines in California, USA (Yee 2007). Diverter effectiveness was tested in three consecutive years (2003-2006) by comparing the number of birds found under the control power lines with the number found under treatment-marked power lines. The number of collisions per span increased with distance from the treatment spans, which also appeared to affect neighboring unmarked spans. More attention has been paid in many studies to the effects of bird diverters attached to transmission power lines. Based on carcass recoveries under these lines, Janss \& Ferrer (1998) reported an $81 \%$ decrease in avian mortality associated with white SFDs on a transmission line in westcentral Spain. Small but significant (9.6\%) decrease in the number of casualties after line marking with SFDs compared to before line marking on experimental lines was observed in central Spain (Barrientos et. al 2012). The overall decrease in the number of carcasses recorded in the sample of 15 experimental lines was 88 birds (189 birds before marking, 101 birds after marking, $47 \%$ reduction in observed casualties). They also did not find any significant difference in mortality reduction comparing marked transmission lines $(220 \mathrm{kV})$ with marked distribution $(15-45 \mathrm{kV})$ lines when all species were considered together.

No bird collisions occurred during a nine-month period of installed FireFly Bird Diverters with 100\% effectiveness in reducing bird mortality in the Lee Kay Ponds area. $70 \%$ of power line overflights were observed after the birds gained altitude by rising up and passing over the transmission line shield wire (Chervick 2004). Collision susceptibility may be influenced by flight behavior. Birds such as ducks, swans and geese tend to form large flocks and fly closely grouped together over the power lines. Our results suggest that individuals grouped in large flocks reacted better and at a greater distance from marked power lines. This is in line with the results of Crowder (2000), who observed that flocks with $>10$ individuals reacted at greater distances to power lines than single birds, suggesting that with more birds scanning for obstacles, flocks can adjust their flight path faster and better avoid power lines. Despite these studies and our findings, flocking species still seem to be more vulnerable to collision than solitary bird species (Crowder \& Rhodes 2002, Drewitt \&
Langstone 2008) when they fly closely grouped together, because birds at the rear of the flock have their vision somewhat occluded by those at the front, and they are more dependent on flock response to obstacle avoidance (Jenkins et al. 2010). This was also confirmed by our above-mentioned observation of a mute swan collision with a marked line. Moreover, collisions of cranes with high numbers of killed or crippled individuals occurred mainly in the case of large flocks when suddenly flushed upward, towards the powerline (Murphy et al. 2009). Flocks of birds could collide with a nearby power line especially as a result of panic after sudden disturbances (APLIC 2012).

After installation of flight diverters, there was a lower proportion of reaction distance observations in the closest distance category 1 (i.e. up to $5 \mathrm{~m}$ ). Conversely, proportions in the more distant categories $2(6-25 \mathrm{~m})$ and $3(>25 \mathrm{~m})$ were dominant, indicating that birds reacted further from lines after diverters were installed. Bird species with highest susceptibility of collision (swans, ducks, herons and geese) reacted to power lines (even in flocks) earlier and at greater distances after diverters were installed. If birds are able to react at greater distances from the lines, the risk of collision with them is most likely reduced, as confirmed in our study as well. Researchers reporting significantly effective diverters, based on collision reduction, have also reported differences in reaction distance (De La Zerda \& Rosselli 2002). In any case, our observations suggest that all diverters may alert bird species to powerlines earlier, giving them more time to react and avoid conductors and/or earth wires.

In our results, the mute swan was the most common species detected as victims of collision before and after installation of bird diverters, 55 vs. 3 carcasses $(94.5 \%$ reduction). Collisions of mute swans often led to many power outages (result of collision-electrocutions) on 22 $\mathrm{kV}$ lines, thus decreasing the power distribution reliability for customers.

A similar reduction of $95 \%$ in swan collision rates in response to fitting flight diverters in 2007 compared to 2006 was observed on $135 \mathrm{kV}$ power lines in Abberton Reservoir Special Protection Area, England (Frost 2008). 500 red 'SWAN-FLIGHT Diverters' (320 mm long, 175 $\mathrm{mm}$ diameter) were installed at $5 \mathrm{~m}$ intervals along a 1.5 $\mathrm{km}$ length of the power lines. $100 \%$ reduction in collisions was found for the SWAN-FLIGHT Diverter in a study by Rasmussen (2001), and quicker reactions to a marked 69 $\mathrm{kV}$ line by sandhill cranes after the line was marked with FireFly Bird Diverters (Murphy et al. 2009). 
Gális M \& Ševčík M: Monitoring of effectiveness of bird flight diverters in preventing bird mortality

from powerline collisions in Slovakia

Although our results indicate higher levels of effectiveness for all three types of diverters used, further study of different habitats and bird species composition is needed especially on distribution power lines worldwide. They are often located close to the habitats used by many species with the highest susceptibility risk of collision, especially if the power line is close to their area of taking off or landing. Many devices designed to increase line visibility may not be effective in heavy fog, at night or in low-light conditions. It is therefore also necessary to test different types of products especially for species with nocturnal flight habits.

\section{References}

APLIC (Avian Power Line Interaction Committee) 1994: Mitigating Bird Collisions With Power Lines: the state of the art in 1994. Edison Electric Institute, Washington, D.C.

APLIC (Avian Power Line Interaction Committee) 2012: Reducing Avian Collisions with Power Lines: The State of the Art in 2012. Edison Electric Institute and APLIC. Washington, D.C.

Bahat O 2008: Wintering black storks (Ciconia nigra) cause severe damage to transmission lines in Israel: a study on the risk and mitigation possibilities. In: Proceedings of the EDM and EPRI International Conference on Overhead Lines. 31 March-3 April 2008. Fort Collins, Colorado.

Barrientos R, Alonso JC, Ponce C \& Palacín C 2011: Meta-analysis of the effectiveness of marked wire in reducing avian collisions with power lines. Conservation Biology 25: 893-903. DOI: 10.1111/j.15231739.2011.01699.x.

Barrientos R, Ponce C, Palacín C, Martín CA, Martín B \& Alonso JC 2012: Wire marking results in a small but significant reduction in avian mortality at power lines: A BACI designed study. PLoS ONE, 7(3): 110. DOI:10.1371/journal.pone.0032569.

Beaulaurier DL 1981: Mitigation of bird collisions with transmission lines. Bonneville Power Admin., U.S. Department of Energy, Portland.

Bernardino J, Bevanger K, Barrientos R, Dwyer J, Marques A, Martins R, Shaw J, Silva J \& Moreira F 2018: Bird collisions with power lines: State of the art and priority areas for research. Biological Conservation 222: 1-13. DOI: 10.1016/j.biocon. 2018.02.029.

Bevanger K 1998: Biological and conservation aspects of bird mortality caused by electricity power lines: a review. Biological Conservation 86: 67-76. DOI:
10.1016/S0006-3207(97)00176-6.

Bevanger K 1999: Estimating bird mortality caused by collision and electrocution with power lines; a review of methodology, 29-56. In: Janss GFE \& Ferrer $\mathrm{M}$ (eds), Birds and power lines. Collision, electrocution and breeding. Quercus, Madrid.

Bevanger K \& Brøseth H 2004: Impact of power lines on bird mortality in a subalpine area. Animal Biodiversity and Conservation 27: 67-77.

Bolker BM, Brooks ME, Clark CJ, Geange S, Poulsen JR, Stevens MHH \& White JSS 2009: Generalized linear mixed models: a practical guide for ecology and evolution. Trends in Ecology \& Evolution 24(3): 127-135.

Brown WM 1993: Avian collisions with utility structures: biological perspectives, 12-13. In: APLIC, Proc. of the Intl. Workshop on Avian Interactions with Utility Structures, 13-16 September 1992, Miami, Florida. Electric Power Research Institute and Avian Power Line Interaction Committee, Palo Alto.

Brown WM \& Drewien RC 1995: Evaluation of two power line markers to reduce crane and waterfowl collision mortality. Wildlife Society Bulletin 23: 217227. DOI: https://www.jstor.org/stable/3782794? seq $=1$

Bürkner PCH 2017: brms: An R package for bayesian multilevel models using Stan. Journal of Statistical Software, 80(1): 1-28.

Chervick T 2004: Firefly bird flapper/diverter testing. https://drive-electric.hu/driveelectricnet files/Firefly\%20BirdFlapperLeeKay\%20PondsEfficacy.pdf

Coleman A, Coleman J, Coleman P \& Minton C 2001: A 39 year study of a mute swan Cygnus olor population in the English Midlands. Ardea 89:123-133.

Crowder MR 2000: Assessment of devices designed to lower the incidence of avian power line strikes. $\mathrm{PhD}$ Thesis. Purdue University, West Lafayete, Indiana.

Crowder MR \& Rhodes OE 2002: Relationships between wing morphology and behavioural responses to unmarked power transmission lines: 403410. In: Goodrich-Mahoney JW, Mutrie DF \& Guild CA (eds), The Seventh International Symposium on Environmental Concerns in Rights-of-Way Management. Elsevier, Boston, Massachusetts.

De La Zerda S \& Rosselli L 2002: Mitigating collision of birds in wetland areas in colombia, by marking the ground wire with bird flight diverters (BFD), 395401. In: Goodrich-Mahoney JW, Mutire DF \& Guild CA (eds), The Seventh International Symposium on 
Environmental Concerns in Rights-of-Way Management. Elsevier, Oxford.

Drewitt AL \& Langston RHW 2008: Collision effects of wind-power generators and other obstacles on birds. Annals of the New York Academy of Sciences 1134: 233-266. DOI: http://dx.doi.org/10. 1196/annals. 1439.015.

Frost D 2008: The use of 'flight diverters' reduces mute swan Cygnus olor collision with power lines at Abberton Reservoir, Essex, England. Conservation Evidence, 5: 83-91.

Gális M, Deutschová L, Šmídt J, Hapl E \& Chavko J 2016: Vysoká cena za pohodlie alebo rizikovost' elektrických vedení pre vol’ne žijúce druhy vtákov [The high price of human comfort or the riskiness of power line for bird species], 77-79. In: Krumpalová Z, Zigová M, Tulis F (eds), Zborník príspevkov z vedeckého kongresu "Zoológia 2016 " [Proceeding from the science congress "Zoology 2016"], Univerzita Konštantína Filozofa v Nitre, Nitra. [In Slov$\mathrm{ak}]$

Gális M, Deutschová L, Šmídt J, Hapl E \& Chavko J 2017: Nárazy vtáctva do elektrických vedení - fakty a riešenia [Bird collisions with power lines - facts and solutions]. In: Kropil R \& Lešo P (eds), Aplikovaná ornitologia. Zborník abstraktov [Applied ornithology. Book of the abstracts] 2017. Technická univerzita, Zvolen [In Slovak]

Gális M, Deutschová L, Šmídt J, Hapl E \& Chavko J 2018a: Labut' vel'ká - obet' nárazov do elektrických vedení [The mute swan - victim of bird collisions]. In: Bryja J \& Solský M (eds), Zoologické dny. Sborník abstraktů z conference [Zoological Days. Proceedings abstracts from conference]. Ústav biologie obratlovců AV ČR, Praha. [In Slovak]

Gális M, Deutschová L, Šmídt J, Hapl E \& Chavko J 2018b: Bezpečne a plynulo vd'aka projektu LIFE Energia [Safe flights - thanks to LIFE Energy project], 39. In: Kubovčík V \& Stašiov S (eds), Zborník abstraktov z vedeckého kongresu „Zoológia 2018"[Proceeding from the science congress “Zoology 2018”]. Technická univerzita, Zvolen [In Slovak]

Gális M, Slobodník R, Chavko J, Deutschová L, Hapl E \& Šmídt J 2019: Energia v krajine - elektrické vedenia a ochrana prioritných druhov vtákov $\mathrm{v}$ územiach Natura 2000 [Energy in the land - power lines and conservation of priority bird species in Natura 2000 sites], 62. In: Bryja J, Horsák M, Horsáková V, Řehák Z \& Zukal J (eds.), Zooolo- gické dny. Sborník abstraktů z conference [Zoological Days. Proceedings abstracts from conference], Ústav biologie obratlovců AV ČR, Brno.[In Slovak]

Gelman A, Carlin JB, Stern HS, Dunson DB, Vehtari A \& Rubin DB 2013: Bayesian data analysis. Chapman and Hall/CRC, Boca Raton.

Haas D, Nipkow M, Fiedler G, Scheneider R, Haas W \& Schürenberg B 2005: Protecting birds from powerlines. Nature and Environment 140: 90.

Hiltunen E 1953: On electric and telephone wire incidents in birds. Suomen Riista 8: 70-76, 222-223.

Homan H, Linz G \& Peer B 2001: Dogs increase recovery of passerine carcasses in dense vegetation. Wildlife Society Bulletin. 29: 292-296. DOI: 10.2307/3784011.

Janss GFE 2000: Avian mortality from power lines: a morphologic approach of a species-specific mortality. Biological Conservation 95: 353-359. DOI: 10.1016/S0006-3207(00)00021-5.

Janss GFE \& Ferrer M 1998: Rate of Bird Collision With Power Lines: Effects of Conductor-Marking and Static Wire-Marking. Journal of Field Ornithology 69: 8-17.

Janss GFE \& Ferrer M 2000: Common Crane and Great Bustard Collision with Power Lines: Collision Rate and Risk Exposure. Wildlife Society Bulletin 28: 675-680. DOI: 10.2307/3783619.

Jenkins A, Smallie J \& Diamond M 2010: Avian collisions with power lines: A global review of causes and mitigation with a South African perspective. Bird Conservation International 20: 263-278. DOI: 10.1017/S0959270910000122.

Jödicke K, Lemke H \& Mercker M 2018: Wirksamkeit von Vogelschutzmarkierungen an Erdseilen von Höchstspannungsfreileitungen. Naturschutz und Landschaftsplanung 50: 286-294.

Karaska D, Trnka A, Krištin A \& Ridzoň J 2015: Chránene vtáčie územia Slovenska [Special Protection Areas in Slovakia]. Štátna ochrana prírody SR, Banská Bystrica. [In Slovak]

Koops FBJ 1994: Collision victims of high-tension lines in the Netherlands and effects of marking, 51-57. In: Red Eléctrica Española. First technical sessions on power lines and the environment. Red Eléctrica Española, Madrid.

Loss SR, Will T \& Marra PP 2012: Direct humancaused mortality of birds: improving quantification of magnitude and assessment of population impact. Frontiers in Ecology and Environment 10: 357-364. DOI: http://dx.doi.org/10.1890/110251. 
Gális M \& Ševčík M: Monitoring of effectiveness of bird flight diverters in preventing bird mortality

from powerline collisions in Slovakia

Manville AM 1999: The ABC's of avoiding bird collisions at communication towers: the next steps, 85104. In: Carlton LR (ed), Avian interactions with utility and communication structures. Workshop proceedings. Electric Power Research Institute, Palo Alto.

Martin GR \& Shaw JM 2010: Bird collisions with power lines: failing to see the way ahead? Biological Conservation 143: 2695-2702. DOI: 10.1016/j.biocon.2010.07.014.

Martin GR 2011: Understanding bird collisions with man-made objects: A sensory ecology approach. Ibis 153: 239-254. DOI: 10.1111/j.1474-919X. 2011.01117.x.

Mojica EK, Watts BD, Paul JT, Voss ST \& Pottie J 2009: Factors contributing to bald eagle electrocutions and line collisions on Aberdeen Proving Ground, Maryland. Journal of Raptor Research 43: 57-61.

Morrison ML 2002: Searcher bias and scavenging rates in bird-wind energy studies. National Renewable Energy Laboratory, Golden. DOI: 10.2172/15000702.

Morkill AE \& Anderson SH 1991: Effectiveness of marking power lines to reduce sandhill crane collisions. Wildlife Society Bulletin 19: 442-449.

Murphy RK, McPherron SM, Wright GD \& Serbousek KL 2009: Effectiveness of avian collision averters in preventing migratory bird mortality from powerline strikes in the Central Platte River, Nebraska. Technical Report. Retrieved June 13, 2019, from http://tiny.cc/et0tiz.

Perrins CM \& Sears J 1991: Collisions with overhead wires as a cause of mortality in mute swans Cygnus olor. Wildfowl 42: 5-11.

Ponce C, Alonso JC, Argandoña G, García-Fernández A \& Carrasco M 2010: Carcass removal by scavengers and search accuracy affect mortality estimates at power lines. Animal Conservation 13: 603-612. DOI: $10.1111 / \mathrm{j} .1469-1795.2010 .00387 . x$.

Prosser P, Nattras C \& Prosser C 2008: Rate of removal of bird carcasses in arable farmland by predators and scavengers. Ecotoxicology and Environmental Safety 71: 601-608.

Quinn M, Alexander S, Heck N \& Chernoff G 2011: Identification of bird collision hotspots along transmission power lines Alberta: an expert-based Geographic Information System (GIS) approach. Journal of Environ. Informatics 18: 12-21. DOI: 10.3808/jei.201100194.
Rasmussen PJ 2001: Problem resolutions for avian interactions at two NSP facilities.In Proc. Avian Interactions with Utility and Communication Structures Workshop. 2-3 December 1999. Charleston, SC. EPRI Technical Report No. 1006907.

Renssen TA, Bruin A, Van de Doorn JH, Gerritsen A, Greven HC \& Kamp J 1975: Vogelsterfte in Nederland tengevolge van aanvaringen met hoogspanningslijnen [Bird mortality in the Netherlands due to collisions with power lines]. Rijksinstitut voor Naturbeheer, CITY. [In Dutch]

R Core Team 2019. R: A language and environment for statistical computing. R Foundation for Statistical Computing, Vienna, Austria. URL http://www.r-project.org/index.html.

Rioux S, Savard JPL \& Gerick AA 2013: Avian mortalities due to transmission line collisions: a review of current estimates and field methods with an emphasis on applications to the Canadian electric network. Avian Conservation and Ecology 8(2): 7. DOI: 10.5751/ACE-00614-080207.

Rubolini D, Gustin M, Bogliani G \& Garavaglia R 2005: Birds and powerlines in Italy: an assessment. Bird Conservation International 15: 131-145. DOI: 10.1017/ S0959270905000109.

Savereno AJ, Savereno LA, Boettcher R \& Haig SM 1996: Avian behavior and mortality at power lines in coastal South Carolina. Wildlife Society Bulletin 24: 636-648.

Shaw JM, Jenkins AR, Smallie JJ \& Ryan PG 2010: Modelling powerline collision risk for the Blue Crane Anthropoides paradiseus in South Africa. Ibis 152: 590-599. DOI: 10.1111/j.1474-919X. 2010.01039.x.

Shaw JM, Reid TA, Schutgens M, Jenkins AR \& Ryan PG 2018: High power line collision mortality of threatened bustards at a regional scale in the Karoo, South Africa. Ibis 160: 431-446. DOI: 10.1111/ibi. 12553.

Sporer MK, Dwyer JF, Gerber BD, Harness RE \& Pandey AK 2013: Marking power lines to reduce avian collisions near the Audubon National Wildlife Refuge, North Dakota. Wildlife Society Bulletin 37: 796-804. DOI: $10.1002 / w s b .329$

Šmídt J \& Gális M. 2018: Monitoring efektivity inštalácie odkloňovacích prvkov na nadzemných elektrických vedeniach $22 \mathrm{kV}$ a $110 \mathrm{kV}$ v Slovenskej republike [Monitoring of effectivenes of installation of bird flight diverters on overhead powerlines 22 $\mathrm{kV}$ and $110 \mathrm{kV}$ in Slovak Republic]. In: Bryja J \& 
Solský M (eds), Zoologické dny. Sborník abstraktů z conference [Zoological Days. Proceedings abstracts from conference], Ústav biologie obratlovců AV ČR, Brno. [In Slovak with English summary]

Šmídt J Hapl E \& Gális M 2019: Methodology of risk assessment for electricity distribution lines in Slovakia with regard to potential bird mortality due to collisions with power lines. Raptor Journal 13: 6173. DOI: $10.2478 /$ srj-2019-0008.

Vehtari A, Gabry J, Yao Y \& Gelman A 2019: loo: Efficient leave-one-out cross-validation and WAIC for Bayesian models. R package version 2.1.0, <URL: https://CRAN.R-project.org/package=loo>.

Williams TC, Williams JM, Williams PG \& Stokstad P 2001: Bird migration through a mountain pass studied with high resolution radar, ceilometers, and census. The Auk 118 (2): 389-403. DOI: 10.1093/ auk/118.2.389.

Ventana Wildlife Society 2009: Evaluating diverter effectiveness in reducing avian collisions with distribution lines at San Luis National Wildlife Refuge Complex, Merced County, California

Wright G, Smith TJ, Murphy R, Runge JT \& Harms RR 2008: Mortality of cranes (Gruidae) associated with powerlines over a major roost on the Platte River, Nebraska. Prairie Naturalist 41: 116-120.

Yee M 2007: Testing the effectiveness of an avian Flight diverter for reducing avian collisions with distribution power lines in the Sacramento Valley, California. California Energy Commission, PIER Energy-Related Environmental Research Program. Retrieved June 13, 2019, from http://tiny.cc/u50tiz. 